\title{
NITROGEN FIXATION AND GROWTH RESPONSE OF Alnus rubra AMENDED WITH LOW AND HIGH METAL CONTENT BIOSOLIDS
}

\author{
Linda S. Gaulke ${ }^{1 *}$; Charles L. Henry²; Sally L. Brown ${ }^{3}$ \\ ${ }^{1}$ Civil and Environmental Engineering, University of Washington - 333 More Hall/Box 352700 - Seattle, WA - \\ 98195-2700 - USA. \\ ${ }_{3}^{2}$ Interdisciplinary Arts and Sciences, University of Washington, Bothell Campus - USA. \\ ${ }^{3}$ College of Forest Resources, University of Washington - Box 352100 - Seattle, WA - 98195 - USA. \\ *Corresponding author<lsg@u.washington.edu>
}

\begin{abstract}
Forest application of biosolids offers a potential environmentally friendly alternative to landfilling. This two-year investigation was designed to analyze the effects of elevated soil metal concentration resulting from the land application of biosolids on the symbiotic, nitrogen (N) fixing relationship between Alnus rubra Bong. (red alder) and Frankia. High metal biosolids and a modernday composted biosolid applied at high loading rates of 250, 500, and $1000 \mathrm{Mg} \mathrm{ha}^{-1}$, were used to represent a worst-case scenario for metal contamination. The high metal biosolids were obtained before the current regulations were formulated and had been lagooned prior to use in this study. Total cadmium $(\mathrm{Cd})$, lead $(\mathrm{Pb})$ and zinc $(\mathrm{Zn})$ in the high metal biosolids were 45, 958, and $2623 \mathrm{mg} \mathrm{kg}^{-1}$ respectively. These metal concentrations are above current regulatory limits in the US. The compost was made using biosolids that are currently produced and had $\mathrm{Cd}, \mathrm{Pb}$ and $\mathrm{Zn}$ of 0.8, 20 and $160 \mathrm{mg} \mathrm{kg}^{-1}$ respectively. Trees were harvested and analyzed for rate of $\mathrm{N}$ fixation (as measured by acetylene reduction activity), biomass, and foliar metals. Soils were analyzed for available N, total carbon and N, pH and total $\mathrm{Cd}, \mathrm{Pb}$ and $\mathrm{Zn}$. Rates of $\mathrm{N}$ fixation were not affected by soil amendment. In year 2, shoot biomass of trees grown in both the compost and high metal amendments were higher than the control. Shoot biomass increased with increasing amount of compost amendments, but decreased with increasing amount of high metal amendments. There was no relationship between soil metal concentration and plant biomass. Foliar Cd and $\mathrm{Pb}$ were below detection for all trees and foliar $\mathrm{Zn}$ increased with increasing amount of both compost and high metal amendment, with concentrations of $249 \mathrm{mg} \mathrm{kg}^{-1}$ for trees grown in the compost amendment and $279 \mathrm{mg} \mathrm{kg}^{-1}$ for the high metal amendment. The results from this study indicate that the growth of $A$. rubra benefited from both types of biosolids used in the study and that the Alnus/Frankia relationship was not negatively impacted by metal concentrations resulting from the high metal biosolids amendments. Key words: Frankia, cadmium, lead, zinc
\end{abstract}

\section{CRESCIMENTO E FIXAÇÃO DE NITROGÊNIO POR Alnus rubra CULTIVADO SOB FERTILIZAÇÃO COM BIOSÓLIDOS COM ALTOS E BAIXOS TEORES DE METAIS}

RESUMO: A aplicação de biosólidos em florestas representa uma potencial alternativa ambientalmente correta para aterros sanitários. Os efeitos de fertilização de nitrogênio na relação simbiôntica e de fixação de nitrogênio Alnus rubra Bong. (amieiro vermelho) e Frankia foram avaliados em um estudo de campo conduzido por dois anos. Um biosólido com concentração de metais muito acima dos marcos regulatórios ( $45 \mathrm{mg} \mathrm{kg}^{-1} \mathrm{Cd}$; $958 \mathrm{mg} \mathrm{kg}^{-1} \mathrm{~Pb} ; 2623 \mathrm{mg} \mathrm{kg}^{-1} \mathrm{Zn}$ ) produzido há mais de 25 anos e um biosólido composto recente foram aplicados nas doses de 250, 500 e $1000 \mathrm{Mg} \mathrm{ha}^{-1}$, representando um cenário pior possível de concentração de metais. Ao final do segundo ano, a biomassa da parte aérea das plantas cultivadas sob ambos os compostos era maior que a das plantas controle, mas não foi observada inter-relação entre a concentração de metais no solo e a biomassa das plantas. As concentrações de $\mathrm{Cd}$ e $\mathrm{Pb}$ foliares permaneceram abaixo do nível de detecção em todas as plantas, mas a concentração de Zn foliar aumentou proporcionalmente ao aumento da adição do bioremediador, atingindo concentrações de $249 \mathrm{mg} \mathrm{kg}^{-1}$ e $279 \mathrm{mg} \mathrm{kg}^{-1}$ para os tratamentos alto metal e composto, respectivamente. Embora não tenham sido registrados efeitos negativos do biosólido com altos teores de metais, outras rotas de exposição podem levar a possíveis impactos ecológicos.

Palavras-chave: Frankia, cádmio, chumbo, zinco 


\section{INTRODUCTION}

As a result of pre-treatment regulations, metal concentrations in biosolids in the US have been greatly reduced over historic levels. As wastewater treatment programs outside of the US become more common, questions will arise on appropriate metal limits for land application of these materials. There are still uncertainties around the potential for the metals in biosolids to have a negative effect on soil ecosystems (Horswell et al., 2003). The bioavailability of metals to soil microorganisms is a factor to be considered in this evaluation. For example, in the UK limits for total zinc (Zn) in biosolids were set to protect Rhizobium leguminosarum biovar trifolii (Giller et al., 1999; McGrath \& Chaudri, 1999). This action was taken because $R$. leguminosarum was considered an indicator organism (Smith, 1997). Results from a long-term study at the Woburn Market Garden using repeated, high-loading applications of biosolids showed that $R$. leguminosarum had lost its ability to fix nitrogen (N) (Chander \& Brookes, 1993). This decline was attributed to soil Zn concentrations. These results are not definitive however, as other long-term studies looking at $R$. leguminosarum have not seen the same effect (Giller et al., 1998; Obbard \& Jones, 1993; Smith, 1997).

In forestry, an analogous relationship is formed by the Frankiaceae. Frankia are a type of filamentous actinomycete that forms a symbiotic $\mathrm{N}$ fixing relationship with actinorhizal plants (e.g. Alnus). Although both Alnus (Kramer et al. 2000a; b) and Frankia (Richards et al., 2002; Sayed, 2003; Sayed et al., 2000) have exhibited signs of metal tolerance, the effect of soil metals on Frankia is not fully understood. As $R$. leguminosarum has been used as an indicator of microbial health in agricultural systems, $\mathrm{N}$ fixation by Frankia may provide information for microbial health in forest ecosystems.

This study was conducted to evaluate the impact of high cadmium (Cd), lead ( $\mathrm{Pb})$, and $\mathrm{Zn}$ concentrations resulting from the land application of biosolids on the growth of $A$. rubra as well as on the $\mathrm{N}$ fixation of the A. rubra-Frankia relationship.

\section{MATERIALS AND METHODS}

\section{Study Site Description}

This study was conducted at a research for-

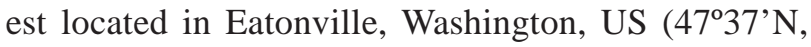
$122^{\circ} 19^{\prime} \mathrm{W}$ ) at the base of the foothills of the Cascade Mountains. Average annual rainfall is $1200 \mathrm{~mm}$, with the rainfall from July and August typically being less than $120 \mathrm{~mm}$ (Pack Forest precipitation records). The study site is $317 \mathrm{~m}$ above sea level and its soil is a well- drained, sandy, glacial outwash soil in the Indianola series (mixed, mesic Dystric Xeropsamments) (NRCS, 2004).

\section{Site Installation}

Prior to installation, which took place in February 2002, the site was densely vegetated with Cytisus scoparius (Scotch Broom) and A. rubra. It was cleared of vegetation and the soil was disked to break up any remaining roots for removal. Two biosolid amendments from the same municipality (King County, Washington) were used in this study, 25 year-old biosolids and composted biosolids, along with a control. The 25 year-old biosolids had been lagooned prior to the start of this study and were used to represent high metal biosolids (hereafter referred to as high metal). They were produced in King County using an anaerobic stabilization process prior to the US Environmental Protection Agency (USEPA) code of federal registry (CFR) Part 503 regulations that set limits on metal concentrations in biosolids for land application (USEPA, 1999). The composted material was produced using current anaerobically stabilized biosolids mixed with sawdust (hereafter referred to as compost). The compost was included as stable biosolids with total metal concentrations representative of the average biosolids currently produced in the US. Total $\mathrm{Cd}, \mathrm{Pb}$ and $\mathrm{Zn}$ in the high metal biosolids were 45,958 , and $2623 \mathrm{mg} \mathrm{kg}^{-1}$, respectively. Biosolids that are currently produced in this wastewater treatment plant and that were used to make the compost used in this study have total $\mathrm{Cd}, \mathrm{Pb}$ and $\mathrm{Zn}$ concentrations of 5, 52 and $825 \mathrm{mg} \mathrm{kg}^{-1}$, respectively. High loading amounts of biosolids were used in this study to represent a worst case scenario for metal loadings; $1000 \mathrm{Mg} \mathrm{ha}^{-1}, 500$ $\mathrm{Mg} \mathrm{ha}^{-1}$ and $250 \mathrm{Mg} \mathrm{ha}^{-1}$ (dry weight basis) of each type of biosolids. The high metal biosolids were used for research purposes only and would not be permitted to be land applied under current US regulations.

This study was designed as a randomized complete block with three replicates of each treatment. Plots were each $2 \mathrm{~m} \times 2 \mathrm{~m}$. There was a $1 \mathrm{~m}$ space between each plot as well as a $3 \mathrm{~m}$ work row in between each replicate.

Amendments were applied evenly to the surface of each plot and then rototilled to a depth of 15$20 \mathrm{~cm}$. Nine bare-root $A$. rubra Bong. seedlings, 40$50 \mathrm{~cm}$ in height, were planted in each plot evenly spaced in a square grid pattern with a $0.5 \mathrm{~m}$ buffer between the outermost trees and the edge of the plot. This resulted in a minimum of a $2 \mathrm{~m}$ space between trees planted in plots with different treatments within the same replicate. There were 27 trees for each treatment ( 9 trees per plot, 3 plots per treatment). The trees 
were purchased from a local nursery. They had been raised from seeds collected in lowlands in Whatcom and Skagit Counties. At the time of planting, the whips had sparse and small nodules and no leaves.

\section{Maintenance}

To eliminate any additional competition for soil available $\mathrm{N}$ weeds within the plot area were treated by direct application of glyphosate herbicide to foliage with a wick applicator. The area surrounding plots was mowed to discourage additional weeds. Deer browsing of A. rubra foliage was initially controlled by biocontrol methods. In December 2002, a 2.5 m chain link fence was built surrounding the entire study and this eliminated access for deer.

\section{Soil/Biosolids Sampling}

Soil samples were collected prior to amendment application, as well as during tree harvest in September 2002 and August 2003. Random grab samples of compost and high metal soil amendments were also collected for analysis prior to installation. Soil samples were collected with a stainless steel probe $(2.5 \mathrm{~cm}$ diameter) in the $0-15 \mathrm{~cm}$ depth range. Three samples were taken from each plot and homogenized. Samples were kept on ice or refrigerated until return to the laboratory when the available $\mathrm{N}$ analysis was performed. Available $\mathrm{N}$ measurements were conducted on field moist samples; all other soil samples were air-dried for remaining analyses.

\section{Available Nitrogen}

Available $\mathrm{N}$ extracts were run on unsieved soil samples in order to prevent removal of the woodchips that compose a large portion of the compost amendment. Soil samples were hand picked to remove any visible rocks (Keeney \& Nelson, 1982; Robertson et al., 1999). A $2 \mathrm{M}$ potassium chloride (KCl) extraction was used to determine available $\mathrm{N}\left(\mathrm{NO}_{2}^{-}, \mathrm{NO}_{3}^{-}\right.$and $\mathrm{NH}_{4}^{+}$) (Keeney \& Nelson, 1982; Robertson et al., 1999). Five $g$ of soil were placed in a glass flask with $50 \mathrm{~mL} 2 \mathrm{M} \mathrm{KCl}$. The flasks were placed on a shaker for one hour, left to settle, and then filtered through Whatman No. 41 filter paper. The solution was analyzed with a Lachat flow injection analyzer using QuickChem method 107-04-1-B for $\mathrm{NO}_{3}^{-} / \mathrm{NO}_{2}^{-}$, and 10-107-06-1-F for $\mathrm{NH}_{4}^{+}$. Ammonium nitrate $\left(\mathrm{NH}_{4} \mathrm{NO}_{3}\right)$ solution standards were used to calibrate for concentrations of $\mathrm{NO}_{3}{ }^{-}$and $\mathrm{NH}_{4}{ }^{+}$from 0 to $1,000 \mu \mathrm{g} \mathrm{kg}$ (calibration curve coefficient $=0.99$ ). Soil water content was used to correct for percent moisture of field moist samples.

\section{pH}

Soils slurries were mixed 1:1 on a volume basis with deionized water and air-dried soil samples and then left to stabilize. The $\mathrm{pH}$ was measured after one hour with an Orion pH meter (Bremner ,1996; Nelson \& Sommers, 1996).

\section{Total Carbon and Nitrogen}

Soil samples were ground with a mortar and pestle and placed into foil packages and weighed on a CAHN C-33 microbalance. Total C and N were determined using a CE-440 elemental analyzer, which combusts samples at $980^{\circ} \mathrm{C}$ (Bremner, 1996; Nelson \& Sommers, 1996). National Institute of Standards and Technology (NIST) standards "Montana soil" and "sludge standard" were used, along with acetanilide and benzoic acid as internal standards. Respective rates of recovery were for standards were: 0.89-0.96 (C, Montana soil), 0.95-1.06 (N, sludge standard), 0.94-1.01 (C, acetanilide), 0.94-0.96 ( $\mathrm{N}$, acetanilide), 0.98 (C, benzoic acid). Total $\mathrm{C}$ and $\mathrm{N}$ were reported as \% on a dry weight basis, and the $\mathrm{C}: \mathrm{N}$ ratio as weight:weight.

\section{Total Metals}

Total $\mathrm{Cd}, \mathrm{Pb}$ and $\mathrm{Zn}$ concentrations were analyzed for both types of amendment and soil samples taken prior to installation, and on soil samples collected during the second year of field work. Phosphorus (P) was also measured on soil samples. Soil samples were air-dried and sieved to $2 \mathrm{~mm}$. A composite $2 \mathrm{~g}$ sample was used for each plot. USEPA method 3050B, acid digestion of sediments, sludges, and soils (USEPA, 1986) was followed for the analysis. Samples were digested and brought to near dryness with concentrated $\mathrm{HNO}_{3}$ and $\mathrm{HCl}$ acids and $30 \% \mathrm{H}_{2} \mathrm{O}_{2}$. Samples were refluxed and then filtered through Whatman No.41 filter paper and brought to volume with DI water. NIST standards "Montana soil" and "sludge standard" were used, along with an internal solution standard consisting of $0.1 \mathrm{mg} \mathrm{L}^{-1}$ each; $\mathrm{Cd}, \mathrm{Pb}$ and $\mathrm{Zn}$. Respective rates of recoveries for standards were: Montana soil $0.96 \mathrm{Cd}, 0.78 \mathrm{~Pb}, 1.01 \mathrm{Zn}$, sludge standard $0.79 \mathrm{Cd}$, $0.83 \mathrm{~Pb}, 0.93 \mathrm{Zn}$, and internal solution standard 1.00 $\mathrm{Cd}, 0.99 \mathrm{~Pb}$, and $1.06 \mathrm{Zn}$. Samples were analyzed on a Perkin Elmer Optima 3300DV inductively coupled plasma optical emission spectrometer (ICP-OES) at a 1:10 dilution. Solutions were also rerun for $\mathrm{Cd}$ on a Perkin Elmer AAnalyst 300 atomic absorption spectrometer (FLAA), using flame with no dilution, to confirm the accuracy of the detection limits that were seen with the ICP-OES.

\section{Tree Harvest}

In certain plots, several trees did not survive. The cause of mortality was investigated and determined to be due to either handling of the plants prior to planting, or a hard frost following planting (Edmonds, personal communication, 2002). Two trees from each 
plot were harvested for analysis during the first week of September in 2002, and the last week of August in 2003. In certain cases in year 1 , one tree was harvested per plot to assure adequate biomass for harvest in year 2. In one plot of the compost $1000 \mathrm{t} \mathrm{ha}^{-1}$ treatment no trees were harvested in year 1 . As is described in the results section, the mortalities were not related to tree yield or metal concentration. Missing values for this treatment was estimated as outlined in Zar (1996), including a correction for the sum of squares bias. For the second harvest, two trees were harvested from all plots in all treatments. For both harvests, results from each tree were averaged and the average was used as a single value from each plot for statistical analysis. At the end of year one, trees were thinned in each plot so that a maximum of 4 trees remained for a treatment total of 12 trees. This was done to reduce competition and shading effects.

\section{Nitrogen Fixation}

Relative rates of $\mathrm{N}$ fixation were measured as acetylene reduction activity (ARA) and reported as micromoles $\mathrm{C}_{2} \mathrm{H}_{4}$ produced per gram of nodule used in the assay (dry weight basis) per hour $\left(\mu \mathrm{mol} \mathrm{C}_{2} \mathrm{H}_{4} \mathrm{~g}^{-1}\right.$ $\mathrm{h}^{-1}$ ) as described in Hardy et al. (1973). Two trees from each plot were harvested for analyses during the first week of September in 2002, and the last week of August in 2003. Values for both trees were averaged and a single value per plot was used for statistical analysis. This time of year was selected for tree harvesting to allow for a reasonably complete growing season for comparison of biomass. In addition, it was determined based on reported midday observations of $A$. rubra ARA in July (34.9 $\left.\mathrm{mol} \mathrm{g}^{-1} \mathrm{hr}^{-1}\right)$, September $(20.9 \mu \mathrm{mol}$ $\left.\mathrm{g}^{-1} \mathrm{hr}^{-1}\right)$ and January $\left(0.1 \mu \mathrm{mol} \mathrm{g}^{-1} \mathrm{hr}^{-1}\right)$ (Teklehaimanot \& Martin, 1999) that ARA would be sufficiently high at this time. Blocks were analyzed on consecutive days at the same time of day to account for diurnal variations. Tree roots were dug up with a garden fork and soil was lightly brushed off. A random selection of nodules was removed from roots with a razor knife, keeping a portion of the root intact to ensure that damage did not occur to nodules, and placed into a $65 \mathrm{~mL}$ glass vial, which was then sealed with rubber septa. $6.5 \mathrm{~mL}$ air was removed from the vial and then 6.5 $\mathrm{mL}$ acetylene $\left(\mathrm{C}_{2} \mathrm{H}_{2}\right)$ was added ( $10 \%$ by volume), and the head space was mixed well. Positive controls (nodules, no $\left.\mathrm{C}_{2} \mathrm{H}_{2}\right)$ and negative controls $\left(\mathrm{C}_{2} \mathrm{H}_{2}\right.$, no nodules) were included. The reaction was left to run for three hours in the dark and then a $3 \mathrm{ml}$ sample was taken from each vial and stored in a vacutainer for transport to the laboratory. Samples were analyzed for ethylene $\left(\mathrm{C}_{2} \mathrm{H}_{4}\right)$ on a SRI 8610C gas chromatograph (GC) with a $60 \mathrm{mx} 0.53$ Supelco capillary column using manual injection with nitrogen as the carrier gas (Hardy et al., 1973; Myrold et al., 1999; Weaver \& Danso, 1994). The detection limit for this analysis taking dilution into account was 1.5 micromoles $\mathrm{g} \mathrm{hr}^{-1}$.

\section{Biomass}

Whole trees were harvested for the determination of biomass. Shoots and roots were separated at the soil line for root and shoot biomass measurements in 2002. All nodules were brushed to remove soil and removed from roots for separate biomass evaluations. Plants were oven-dried for 72 hours at $70^{\circ} \mathrm{C}$. Biomass was reported as dry weight in grams. Two trees were harvested from each plot the first year of the study and results were averaged. This average was used as the value for each plot for statistical analysis. For the second year only shoots were harvested as dry cemented soil conditions made it difficult to accurately collect the entire root and nodule system for determination of total biomass. Mean \pm standard deviation is reported in the text.

\section{Foliar total metals}

Fifteen leaves were randomly collected from each harvested tree the second year, and combined as one sample for each plot. Leaves were dried at $70^{\circ} \mathrm{C}$ for 72 hours to determine dry weight. Foliar total metals were determined using a laboratory adaptation of the Association of Analytical Communities (AOAC) method 3.014(a) ((AOAC, 1984) as described in Brown et al. (2004). Two g of each composite leaf sample were ashed in glass beakers at $480^{\circ} \mathrm{C}$ for 16 h. Ashed samples were dissolved in $2 \mathrm{~mL} \mathrm{HNO}_{3}$, placed on a hotplate and heated until near dryness. Samples were then refluxed with $10 \mathrm{~mL} 3 \mathrm{~N} \mathrm{HCl}$. Samples were brought to a final volume of $25 \mathrm{~mL}$ with DI $\mathrm{H}_{2} 0$ and centrifuged. NIST standards "orchard leaves" and "spinach leaves" were used, along with an internal solution standard consisting of $0.1 \mathrm{mg} \mathrm{L}^{-1}$ each; $\mathrm{Cd}, \mathrm{Pb}$ and $\mathrm{Zn}$. Respective recovery rates for standards were; orchard leaves $0.89 \mathrm{~Pb}$ and $1.12 \mathrm{Zn}$, spinach leaves $0.84 \mathrm{Cd}, 100 \mathrm{~Pb}, 0.98 \mathrm{Zn}$; and internal solution standard $1.00 \mathrm{Cd}, 0.99 \mathrm{~Pb}$, and $1.06 \mathrm{Zn}$. Samples were analyzed on a Perkin Elmer Optima 3300DV ICP-OES. Cadmium was also analyzed on Perkin Elmer AAnalyst 300 (AA) with flame to verify detection limits that were seen with the ICP-OES.

\section{Statistical Analysis}

Statistical analyses were performed using SPSS 12 for Windows (SPSS Inc., 2003). Data was checked for normality by visual inspection and confirmed using Kolmogorov-Smirnov tests. Analysis of variance (ANOVA) was used to test for main effects of treatment and treatment versus rate interactions $(P$ 
$=0.05)$. Means were separated using Duncan's multiple range test $(P=0.05)$. Linear regression was used to evaluate relationships between treatment rate and measured properties, and correlation was evaluated among measured properties $(P=0.05)$.

\section{RESULTS AND DISCUSSION}

\section{Soil Properties}

Results of total soil $\mathrm{Cd}, \mathrm{Pb}$ and $\mathrm{Zn}$ for year 2 are presented in Table 1. The value for the control soils (1.9 $\mathrm{mg} \mathrm{kg}^{-1}$ ) was relatively high as compared to reported average values in the Pacific Northwest $(\sim 0.30$ $\mathrm{mg} \mathrm{kg}{ }^{-1}$ ), but were within the range of naturally occurring soil Cd (Traina, 1999). Metal concentrations were similar for the control and compost treatments and increased with increased loading of high metal biosolids. The metal concentrations in the high metal treatments were at or above those at which negative impacts on soil microbial function have been observed. For example, at total soil Cd $12.4 \mathrm{mg} \mathrm{kg}^{-1}$ and Zn $435 \mathrm{mg} \mathrm{kg}^{-1}$, Giller et al. (1989) found Rhizobium isolated from nodules of white clover had lost their ability to symbiotically fix $\mathrm{N}$.

Soil $\mathrm{NO}_{3}^{-}, \mathrm{NH}_{4}^{+}$, total $\mathrm{C}, \mathrm{N}, \mathrm{C}: \mathrm{N}$ and $\mathrm{pH}$ are

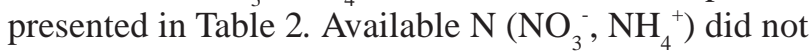
increase with increasing application rates in either the compost or high metal amendments the first year. This may have been a result of the high loading applications used, with a high percentage of the surface soil consisting of amendment. However, for the second year, both soil $\mathrm{NO}_{3}^{-}$and $\mathrm{NH}_{4}{ }^{+}$increased with increasing applications of both amendments. Total $\mathrm{C}$ and $\mathrm{N}$, along with the $\mathrm{C}: \mathrm{N}$ ratio, decreased from year 1 to year 2 in all of the compost treatments, but in all other treatments was similar from year 1 to year 2 . The C:N ratio (9:1) of the high metal biosolids was within the range commonly seen prior to land application, indicating that the material had not decomposed over time. The slow rate of decomposition of these materials potentially resulted from their storage in an anaerobic en- vironment for 25 years prior to this study (Henry et al., 1999). In this study, biosolids applied at $13.4 \mathrm{t} \mathrm{ha}^{-1}$ supplied plant $\mathrm{N}$ equivalent to $140 \mathrm{~kg} \mathrm{ha}^{-1}$ urea. Both foliar $\mathrm{N}$ and tree growth in the biosolid treatments are evidence that this rate was sufficient to meat the $\mathrm{N}$ needs of the trees. For this study, total $\mathrm{N}$ provided by all plots receiving either compost or high metal biosolids was well in excess indicating that there was sufficient $\mathrm{N}$ for plant growth.

Soil $\mathrm{pH}$ in the high metal treatments ( $\mathrm{pH}$ 4.14.7) was lower than the control ( $\mathrm{pH}$ 5.1), with the second year high metal $1000 \mathrm{t} \mathrm{ha}^{-1}$ treatment having the lowest $\mathrm{pH}$ of all treatments ( $\mathrm{pH}$ 4.1). Low $\mathrm{pH}$ has been found to be an important regulating factor for $\mathrm{N}$ fixation in Rhizobium. Ibekwe et al. (1997) grew $R$. leguminosarum bv. trifolii in high and low metal biosolids amended soils under varying $\mathrm{pH}$ conditions (pH range 4.4 to 6.4 ) and found that $\mathrm{N}$ fixation as ARA was greater in all high $\mathrm{pH}$ treatments as compared with lower ones. In addition, the number of Rhizobium was reduced in all of the low $\mathrm{pH}$ soils, including the controls, resulting in reduced and ineffective nodulation. The concentrations for $\mathrm{Cd}\left(\cong 1.0\right.$ and $\left.4 \mathrm{mg} \mathrm{kg}^{-1}\right)$ and $\mathrm{Zn}\left(\cong 133\right.$ and $140 \mathrm{mg} \mathrm{kg}^{-1}$ ) however, were lower than those in the high metal biosolid treatments in this study. It is not known what the optimum $\mathrm{pH}$ range for Alnus and Frankia nodulation and fixation is. Crannell et al. (1994) provide an exhaustive review of studies reporting Alnus and Frankia association at a range of soil $\mathrm{pH}$. They report that Alnus have been shown to nodulate in soils below $\mathrm{pH} \mathrm{4}$, and that one study showed no difference in forest soil nodulation from $\mathrm{pH} 4.5$ to 7.3. The USEPA CFR part 503 does not have a recommendation for $\mathrm{pH}$, other than that it be monitored and adjusted over time to ensure proper $\mathrm{pH}$ for ideal crop growth (USEPA, 1993). Based on previous studies, it would be expected that some negative impact on Frankia would be observed as a result of both the metal concentrations and low $\mathrm{pH}$ in the high metal treatments in this study.

Table 1 - Total soil Cd, Pb and Zn concentrations for low metal (compost) and high metal biosolid amended soils. Means and standard deviations are presented.

\begin{tabular}{lcccc}
\hline Treatment & Rate & Soil Cd & Soil Pb & Soil Zn \\
\hline Control & Mg ha $^{-1}$ & $1.2 \pm 0.077$ & $28.3 \pm 15.2$ & $109.5 \pm 52$ \\
Compost & & $3.4 \pm 1.43$ & $39.1 \pm 20.2$ & $161.8 \pm 56$ \\
Compost & 250 & $3.7 \pm 0.32$ & $42.4 \pm 5.3$ & $254.4 \pm 29$ \\
Compost & 500 & $4.0 \pm 0.41$ & $50.2 \pm 3.3$ & $283.2 \pm 55$ \\
High Metal & 1000 & $14.8 \pm 3.71$ & $258.6 \pm 77.5$ & $627.1 \pm 198$ \\
High Metal & 250 & $19.9 \pm 1.05$ & $352.0 \pm 11.7$ & $1012.0 \pm 16$ \\
High Metal & 500 & $32.5 \pm 4.08$ & $623.0 \pm 100$ & $1759.6 \pm 161$ \\
\hline
\end{tabular}




\section{Nitrogen Fixation (as ARA) and Nodule Biomass}

Rates of N fixation as ARA (Table 3) were generally higher in the first year of the study (35-198 $\mu \mathrm{mol}$ $\left.\mathrm{g}^{-1} \mathrm{~h}^{-1}\right)$ than the second (17-37 $\left.\mu \mathrm{mol} \mathrm{g}^{-1} \mathrm{~h}^{-1}\right)$, and were also higher than many reported values of ARA for $A$. rubra. A range of reported values in the literature was 3.2-90 $\mu \mathrm{mol} \mathrm{g}^{-1} \mathrm{~h}^{-1}$ (Binkley, 1981; Monaco et al., 1982; Rojas et al., 2001; Teklehaimanot \& Martin, 1999). The conditions of these studies were more reflective of native growing conditions, Alnus sp. are commonly found in poor-quality, low-productivity soils. The high amount of biosolids that were used in this study created unusual growing conditions. The first year ARA for compost $\left(108 \pm 52 \mu \mathrm{mol} \mathrm{g}^{-1} \mathrm{~h}^{-1}\right)$ and high metal $\left(105 \pm 100 \mu \mathrm{mol} \mathrm{g}^{-1} \mathrm{~h}^{-1}\right)$ treatments were relatively high as compared to the controls $\left(35 \pm 16 \mu \mathrm{mol} \mathrm{g}^{-1} \mathrm{~h}^{-1}\right)$. However, as a consequence of high variability, this increase in ARA can only be viewed as a trend $(P=$ 0.05 ). Similar variability has also been seen with other studies of Alnus sp. (Beaupied et al., 1990; Rytter et

Table 2 - Mean and standard deviation for soil $\mathrm{NO}_{3}{ }^{-}, \mathrm{NH}_{4}^{+}$, total C, $\mathrm{N}, \mathrm{C}: \mathrm{N}$ ratio and $\mathrm{pH}$ by treatment type and amount, both years of the study.

\begin{tabular}{|c|c|c|c|c|c|c|c|}
\hline \multicolumn{8}{|c|}{ Year 1} \\
\hline Treatment & Rate & $\mathrm{NO}_{3}^{-}$ & $\mathrm{NH}_{4}^{+}$ & $\mathrm{C}$ & $\mathrm{N}$ & $\mathrm{C}: \mathrm{N}$ & $\mathrm{pH}$ \\
\hline & $\mathrm{Mg} \mathrm{ha}^{-1}$ & \multicolumn{2}{|c|}{ - } & \multicolumn{2}{|c|}{ - } & & \\
\hline Control & 0 & $30 \pm 18^{*}$ & $8 \pm 4^{*}$ & $1 \pm 1 \mathrm{a}$ & $0.1 \pm 0.1 \mathrm{a}$ & $10 \pm 2 \mathrm{a}$ & $5.1 \pm 0.3 b$ \\
\hline Compost & 250 & $109 \pm 95 *$ & $37 \pm 8^{*}$ & $19 \pm 8 \mathrm{c}$ & $0.6 \pm 0.2 \mathrm{~b}$ & $30 \pm 1 \mathrm{c}$ & $5.3 \pm 0.1 \mathrm{bc}$ \\
\hline Compost & 500 & $47 \pm 2 *$ & $61 \pm 16^{*}$ & $31 \pm 5 d$ & $1.2 \pm 0.1 \mathrm{c}$ & $26 \pm 2 b$ & $5.5 \pm 0.1 \mathrm{c}$ \\
\hline Compost & 1000 & $221 \pm 229 *$ & $48 \pm 14^{*}$ & $35 \pm 6 \mathrm{~d}$ & $1.2 \pm 0.3 \mathrm{c}$ & $29 \pm 2 \mathrm{c}$ & $5.3 \pm 0.3 \mathrm{bc}$ \\
\hline High metal & 250 & $98 \pm 20^{*}$ & $46 \pm 17^{*}$ & $4 \pm 2 \mathrm{ab}$ & $0.4 \pm 0.2 \mathrm{ab}$ & $10 \pm 1 \mathrm{a}$ & $4.6 \pm 0.2 \mathrm{a}$ \\
\hline High metal & 500 & $222 \pm 98^{*}$ & $110 \pm 43^{*}$ & $7 \pm 1 \mathrm{ab}$ & $0.7 \pm 0.1 \mathrm{~b}$ & $9 \pm 1 \mathrm{a}$ & $4.7 \pm 0.1 \mathrm{a}$ \\
\hline High metal & 1000 & $159 \pm 35^{*}$ & $61 \pm 41^{*}$ & $12 \pm 3 \mathrm{bc}$ & $1.4 \pm 0.3 \mathrm{c}$ & $9 \pm 0$ a & $4.6 \pm 0.1 \mathrm{a}$ \\
\hline \multicolumn{8}{|c|}{ Year 2} \\
\hline \multirow[t]{2}{*}{ Treatment } & Rate & $\mathrm{NO}_{3}^{-}$ & $\mathrm{NH}_{4}^{+}$ & $\mathrm{C}$ & $\mathrm{N}$ & $\mathrm{C}: \mathrm{N}$ & $\mathrm{pH}$ \\
\hline & $\mathrm{Mg} \mathrm{ha}^{-1}$ & \multicolumn{2}{|c|}{ 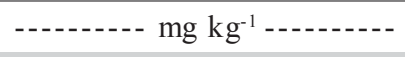 } & \multicolumn{2}{|c|}{ - } & & \\
\hline Control & 0 & $9 \pm 8$ a & $5 \pm 6$ a & $2 \pm 1 \mathrm{a}$ & $0.3 \pm 0.2 \mathrm{a}$ & $7 \pm 1 \mathrm{a}$ & $5.1 \pm 0.5 \mathrm{c}$ \\
\hline Compost & 250 & $29 \pm 28$ a & $29 \pm 15$ a & $10 \pm 4 \mathrm{ab}$ & $0.4 \pm 0.2 \mathrm{a}$ & $22 \pm 2 \mathrm{bc}$ & $4.9 \pm 0.1 \mathrm{bc}$ \\
\hline Compost & 500 & $30 \pm 26 a$ & $76 \pm 62 a$ & $18 \pm 7 \mathrm{bc}$ & $0.9 \pm 0.2 \mathrm{bc}$ & $20 \pm 3 b$ & $5.1 \pm 0.1 \mathrm{c}$ \\
\hline Compost & 1000 & $134 \pm 40 \mathrm{~b}$ & $192 \pm 135 b$ & $23 \pm 8 \mathrm{c}$ & $1.0 \pm 0.4 \mathrm{c}$ & $24 \pm 2 \mathrm{c}$ & $5.0 \pm 0.1 \mathrm{bc}$ \\
\hline High metal & 250 & $19 \pm 7 \mathrm{a}$ & $14 \pm 5 a$ & $4 \pm 1 \mathrm{a}$ & $0.5 \pm 0.0 \mathrm{ab}$ & $8 \pm 1 \mathrm{a}$ & $4.6 \pm 0.2 b$ \\
\hline High metal & 500 & $50 \pm 13 a$ & $26 \pm 23 a$ & $6 \pm 3 a$ & $0.6 \pm 0.2 \mathrm{abc}$ & $9 \pm 2 a$ & $4.6 \pm 0.2 \mathrm{~b}$ \\
\hline High metal & 1000 & $139 \pm 15 b$ & $77 \pm 30 \mathrm{a}$ & $9 \pm 2 a$ & $0.9 \pm 0.2 \mathrm{c}$ & $9 \pm 1 \mathrm{a}$ & $4.1 \pm 0.1 \mathrm{a}$ \\
\hline
\end{tabular}

Different letters following numbers indicate significantly different values using the Duncan post-hoc mean separation procedure $(P=$ $0.05)$, values followed by *are not statistically different

Table 3 - Mean and standard deviation for acetylene reduction activity (ARA) and nodule biomass for both years of the study. Total nodule biomass was not measured in year two.

\begin{tabular}{|c|c|c|c|c|}
\hline \multirow{2}{*}{ Treatment } & \multirow{2}{*}{ Rate } & Year 1 & Year 1 & Year 2 \\
\hline & & ARA & Nodule Biomass & ARA \\
\hline & $\mathrm{Mg} \mathrm{ha}{ }^{-1}$ & $\mu \mathrm{mol} \mathrm{C}{ }_{2} \mathrm{H}_{4} \mathrm{~g}^{-1} \mathrm{hr}^{-1}$ & $\mathrm{~g}$ & $\mu \mathrm{mol} \mathrm{C}{ }_{2} \mathrm{H}_{4} \mathrm{~g}^{-1} \mathrm{hr}^{-1}$ \\
\hline Control & 0 & $35 \pm 16$ & $0.23 \pm 0.17$ & $23 \pm 14$ \\
\hline Compost & 250 & $105 \pm 69$ & $0.19 \pm 0.07$ & $37 \pm 23$ \\
\hline Compost & 500 & $99 \pm 64$ & $0.21 \pm 0.10$ & $19 \pm 8$ \\
\hline Compost & 1000 & $100 \pm 47$ & $0.60 \pm 0.29$ & $19 \pm 5$ \\
\hline High metal & 250 & $51 \pm 57$ & $0.37 \pm 0.28$ & $29 \pm 36$ \\
\hline High metal & 500 & $198 \pm 103$ & $0.37 \pm 0.14$ & $33 \pm 30$ \\
\hline High metal & 1000 & $74 \pm 95$ & $0.21 \pm 0.07$ & $17 \pm 25$ \\
\hline
\end{tabular}


al., 1991; Verghese \& Misra, 2000), and is to be expected as Alnus and Frankia are "wild type" organisms and are more heterogeneous than agronomic Rhizobium and legume species. Nodule biomass (Table 3) was also not statistically different between treatments (only collected first year) and no relation to ARA was seen $(P=0.05)$.

Decreased nodulation and suppression of $\mathrm{N}$ fixation as a result of soil available $\mathrm{N}$ has been well documented for Alnus (Huss-Danell et al., 2001; Martin et al., 2003; Wall, 2000), but in this study the reverse was observed. At the $500 \mathrm{Mg} \mathrm{ha}^{-1}$ amendment the high metal biosolids amendment added $12 \mathrm{Mg}$ total $\mathrm{N} \mathrm{ha}^{-1}$ and the compost $9 \mathrm{Mg}$ total $\mathrm{N}^{-1}$. The portion of total $\mathrm{N}$ in the amendments that is plant available over a growing season will vary; however, in all likelihood the amount of added $\mathrm{N}$ that amendments supplied was more than the plants were able to use for a single season. In a study by Baker et al. (1997), although the addition of $\mathrm{NO}_{3}^{-}$to A. glutinosa was found to have an inhibitory affect on ARA, addition of $\mathrm{NH}_{4}^{+}$did not. $\mathrm{NH}_{4}^{+}$was found to reduce nodule size, but not rates of ARA. A similar response with A. rubra was seen in this study, trees grown in biosolid amended soils had higher rates of ARA than trees grown in soils that had been amended with an equivalent amount of urea. This increase in ARA may be related to the $\mathrm{P}$ in the amendments as increases in nodulation and $\mathrm{N}$ fixation with $\mathrm{P}$ additions have also been well documented (Gentili \& Huss-Danell, 2003; Uliassi \& Ruess, 2002). Prior to installation of the study, total P in high metal and compost amendments were 13.3 and $8.0 \mathrm{~g} \mathrm{~kg}^{-1}$ respectively. However, $\mathrm{P}$ also does not solely explain the high rates of ARA seen in the first year of this study, as the rates of ARA were all lower the second year when $P$ concentrations would still be relatively high. In addition, background soil total $\mathrm{P}$ concentrations were $1.54 \mathrm{~g} \mathrm{~kg}^{-1}$, which is relatively high (Brady \& Weil, 2002).

These results suggest that the Alnus-Frankia relationship in this study was not negatively impacted by the high metal treatments. Metals resistance of Frankia has been studied in controlled environments with metals added as salts. Sayed et al. (2000) grew 3 strains of Frankia in culture with $\mathrm{Pb}$, cobalt (Co) and aluminum (Al) added as salts and measured their relative growth rates and found tolerance to metals varied with strain. Richards et al. (2002) grew twelve strains of Frankia on plates or in broth with metals added as salts $\left(\mathrm{AgNO}_{3}, \mathrm{Na}_{2} \mathrm{HAsO}_{4}, \mathrm{NaAsO}_{2}, \mathrm{CdCl}_{2}\right.$, $\mathrm{CoCl}_{2}, \mathrm{~K}_{2} \mathrm{CrO}_{4}, \mathrm{CuCl}_{2}, \mathrm{NiCl}_{2}, \mathrm{~Pb}\left(\mathrm{NO}_{2}\right)_{2}, \mathrm{~K}(\mathrm{SbO}) \mathrm{C}_{4} \mathrm{H}_{4} \mathrm{O}_{6}$ and $\mathrm{Na}_{2} \mathrm{SeO}_{2}$ ) and found some strains showed resistance to heavy metals, but again, the results varied among strains. As this study was conducted with wild type Frankia and profiling of the organisms was beyond the scope of this research, it is not possible to draw conclusions on the response of specific strains present at the field site.

\section{Shoot Biomass}

At the time of the first years tree harvest there were no differences in biomass, but the second year biomass did differ by treatment type $(P=0.05)$, (Figure 1). The control trees had the smallest shoot biomass (120 $\pm 66 \mathrm{~g})$, followed by trees in the high metal treatments (327 $\pm 78 \mathrm{~g}$ ) with the highest yield in the compost treatments $(544 \pm 200 \mathrm{~g})$. In compost treatments, there was a moderate trend of increased biomass with increasing amount of amendment $\left(\mathrm{r}^{2}=\right.$ $0.36)$. In the high metal treatments, the trend appeared to be decreasing biomass with increasing application rates.

It is difficult to determine an exact cause for the biomass of trees in the high metal treatments being less than the compost treatments. Although metals have been seen to have an effect on shoot biomass (El-Kenawy et al., 1997), they were not a clear contributor in this study. No correlation was seen for soil metal concentrations and shoot biomass, and shoot biomass was consistently higher in high metal treatments than in the control. This was the case even though soils in these treatments also had lower $\mathrm{pH}$ which results in higher metal bioavailability. Increased yield observed in this study may be the result of the added nutrients in the biosolids outweighing the nega-

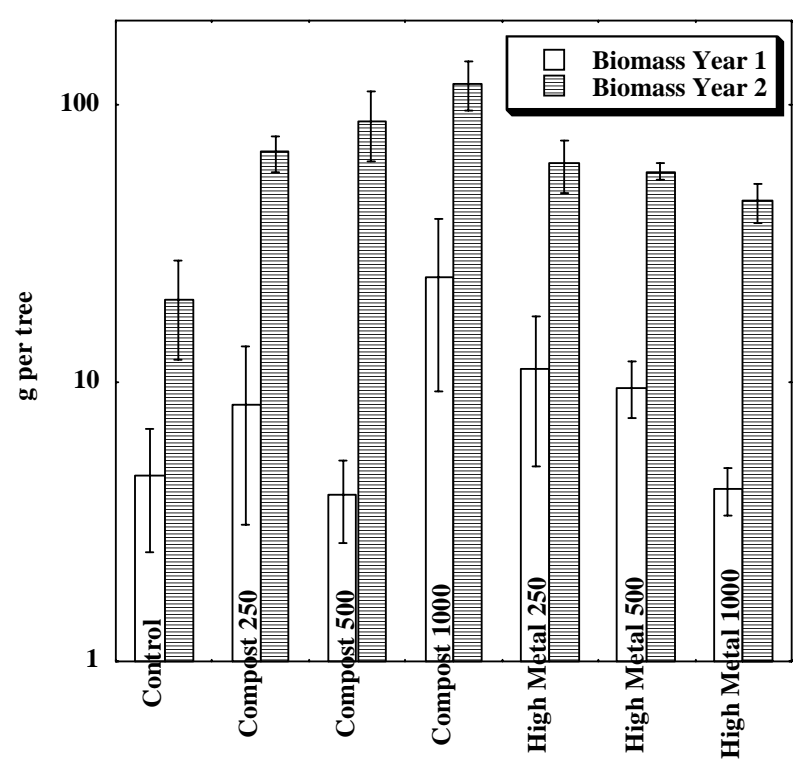

Figure 1 - Shoot biomass results for both years by treatment type and rate. Numbers on bars show average biomass in grams of dry weight for each treatment type. Data, means and standard deviation are shown for two years. 
tive impact of metals. However, Alnus have also exhibited metal tolerance when grown on metal contaminated sites. Kramer et al. grew A. viridis (Sitka alder) in a greenhouse study (Kramer et al., 2000b) and a field study (Kramer et al., 2000a) in biosolids amended copper $(\mathrm{Cu})$ mine tailings and found the greatest uptake of nutrients, largest biomass, and smallest root:shoot in the biosolids amended mine tailings over unamended tailings, as well as uncontaminated control soils. Total soil metal concentrations were not reported, but water quality criteria at the site is exceeded for $\mathrm{Cd}, \mathrm{Cu}$ and $\mathrm{Zn}$ during spring snowmelt, with $\mathrm{Cu}$ being the highest concern (Forest_Service, 2004). Frankia in culture has also shown metal tolerance, as discussed above. Foliar uptake of metals as a metric of bioavailability also did not show a negative impact and is discussed next.

\section{Foliar Metals}

Foliar $\mathrm{Cd}$ and $\mathrm{Pb}$ were below detection in all treatments, foliar $\mathrm{Zn}$ results are presented in Figure 2. Detection limits for $\mathrm{Cd}, \mathrm{Pb}$ and $\mathrm{Zn}$ were 0.6, 1.2 and $0.6 \mathrm{mg} \mathrm{kg}^{-1}$ respectively. Although there was a weak relationship between increasing amount of amendment and increased foliar $\mathrm{Zn}\left(\mathrm{r}^{2}=0.29\right)$, there was no difference in foliar $\mathrm{Zn}$ as a function of type of biosolid amendments. Total soil $\mathrm{Zn}$ in the $1000 \mathrm{Mg} \mathrm{ha}{ }^{-1}$ compost treatment was $279 \mathrm{mg} \mathrm{kg}^{-1}$, with a corresponding foliar Zn of $249 \mathrm{mg} \mathrm{kg}^{-1}$; total soil Zn in the 1000 $\mathrm{Mg} \mathrm{ha}^{-1}$ high metal treatment was $1760 \mathrm{mg} \mathrm{kg}^{-1}$, with a foliar $\mathrm{Zn}$ of $274 \mathrm{mg} \mathrm{kg}^{-1}$. Based on biomass results, visual appearance and comparison to values in the lit-

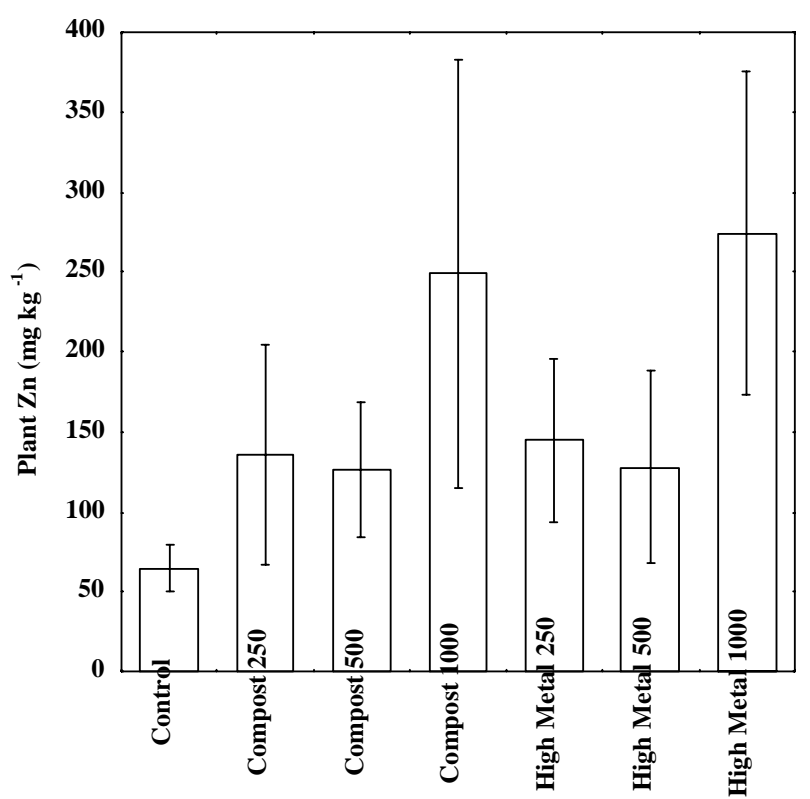

Figure 2 - Average values for foliar Zn by treatment type and rate for the second year of the study. Data, means and standard deviation are shown. erature, plants in all treatments showed no evidence of phytotoxicity. Values for foliar metals in A. rubra growing under similar conditions were not found in the literature, but foliar metals were low as compared to reported values for other Alnus sp. growing in high metal soils with biosolid amendments. For example, Sopper (1989) found foliar $\mathrm{Cd}, \mathrm{Pb}$ and $\mathrm{Zn}$ of $\mathrm{A}$. glutinosa to be $3-5,76-140$, and $807-2070 \mathrm{mg} \mathrm{kg}^{-1}$ respectively at a highly contaminated $\mathrm{Zn}$ smelter site amended with biosolids and ash. Surface $(0-30 \mathrm{~cm})$ soil concentrations were: $31,316 \mathrm{mg} \mathrm{Zn} \mathrm{kg}{ }^{-1}$, 5,225 mg $\mathrm{Pb} \mathrm{kg}^{-1}$, and 1,248 $\mathrm{mg} \mathrm{Cd} \mathrm{kg}^{-1}$. Kramer et al. (2000a) saw foliar Zn of $546 \mathrm{mg} \mathrm{kg}^{-1}$ without growth being negatively impacted. A wide variation in uptake patterns is seen even within genotypes of the same species, so it is unknown exactly how these values compare to A. rubra, but if comparison is valid it appears that metals in the high metal treatments were mostly not in a bioavailable form. The factors contributing to low metal availability in this study are not clear, although biosolids used as soil amendments have been shown to increase the sorption of heavy metals ( $\mathrm{Li}$ et al., 2001), and reduce the bioavailability of metals (Brown et al., 1998; DeVolder et al., 2003). Soil organic matter and/or $\mathrm{N}$ could possibly have been a factor in increasing foliar $\mathrm{Zn}$ with increasing amount of both types of biosolid amendments, Hutchinson et al. (1998) found $\mathrm{N}$ added as $\left(\mathrm{NH}_{4}\right)_{2} \mathrm{SO}_{4}$ to increase foliar $\mathrm{Cd}$, and $\mathrm{Zn}$ in tree rings, of Acer saccharum (sugar maple), with foliar $\mathrm{Cd}$ in high and medium treatments being two times the concentrations in the low and control treatments. Untreated soil metals concentrations were 0.06-0.08 and 50-64 mg kg-1 for Cd and $\mathrm{Zn}$ with foliar concentrations of $0.09-0.10$ and $10-25 \mathrm{mg} \mathrm{kg}^{-1}$ for $\mathrm{Cd}$ and $\mathrm{Zn}$. In this study foliar Zn correlated to concentrations of available $\mathrm{N}\left(\mathrm{r}^{2}=0.42\right)$, and total soil $\mathrm{N}\left(\mathrm{r}^{2}=0.44\right)$ more strongly than the correlation to soil $\mathrm{Zn}$ concentrations $\left(\mathrm{r}^{2}=0.26\right)$. Soil $\mathrm{pH}$ was not a predictor of foliar $\mathrm{Zn}$.

\section{CONCLUSION}

This study focused on potential impacts to the Alnus/Frankia relationship as a result of elevated soil metals resulting from the land application of biosolids. For this study, increased growth as a result of biosolids application, without an impact on $\mathrm{N}$ fixation, was the primary response observed for trees grown in both low and high metal concentration biosolids. These results illustrate the potential benefits associated with biosolid application. Although these benefits were observed for both materials, this should not be taken as a justification for permitting land application of high metal biosolids. The metal concentrations of the historic 
biosolids are well above current regulatory limits in the US and would not be suitable for land application. Although tree growth in this instance was enhanced, the potential for negative ecosystem effects as a result of use of these materials was not fully considered in this study. The efficacy of pre-treatment regulations can be seen in the dramatic decrease in total metal concentrations from the historic material and the current day biosolids, both from the same wastewater treatment plant. The full benefits of these materials can be realized if every reasonable attempt is made to reduce contaminant concentrations.

\section{ACKNOWLEDGMENTS}

This study was funded through a grant from King County and the Northwest Biosolids Management Association. The authors are also grateful to Ron Sletten for the assistance he provided with ICP analysis.

\section{REFERENCES}

BAKER, A.; HILL, G.F.; PARSONS, R. Evidence for N feedback regulation of N2 fixation in Alnus glutinosa L. Journal of Experimental Botany, v.48, p.67-73, 1997.

BEAUPIED, H.; MOIROUD, A.; DOMENACH, A.-M.; KURDALI, F.; LENSI, R. Ratio of fixed and assimilated nitrogen in a black alder (Alnus glutinosa) stand. Canadian Journal of Forest Research, v.20, p.1116-1119, 1990.

BINKLEY, D. Nodule biomass and acetylene reduction rates of red alder and Sitka alder on Vancouver Island, B.C. Canadian Journal of Forest Research, v.11, p.281-286, 1981.

BRADY, N.C.; WEIL, R.R. The nature and property of soils. Englewood Cliffs: Prentice Hall, 2002. 960p.

BREMNER, J.M. Nitrogen - total. In: BARTELS, J.M.; BIGHAM, J.M.; SPARKS, D.L.; PAGE, A.L.; HELMKE, P.A.; LOEPPERT, R.H.; SOLTANPOUR, P.N.; TABATABAI, M.A.; JOHNSTON, C.T.; SUMNER, M.E. (Ed.) Methods of soil analysis. Part 3. Chemical methods. Madison: SSSA; ASA, 1996. p.1085-1089.

BROWN, S.L.; CHANEY, R.; ANGLE, J.S.; RYAN, J.A. Organic carbon and the phytoavailability of cadmium to lettuce in longterm biosolids-amended soils. Journal of Environmental Quality, v.27, p.1071-1078, 1998.

BROWN, S.L.; CHANEY, R.L.; HALLFRISCH, J.; RYAN, J.A.; BERTI, W.R. In situ soil treatments to reduce the phyto- and bioavailability of lead, zinc, and cadmium. Journal of Environmental Quality, v.33, p.522-531, 2004.

CHANDER, K.; BROOKES, P.C. Residual effects of zinc, copper and nickel in sewage sludge on microbial biomass in a sandy loam. Soil Biology and Biochemistry, v.25, p.1231-1239, 1993.

CRANNEL, W.K.; TANAKA, Y.; MYROLD, D.D. Calcium and pH interactions on root nodulation of nursery-grown red alder (Alnus Rubra Bong.) seedlings by Frankia. Soil Biology and Biochemistry, v.26, p.607-614, 1994.

DeVOLDER, P.; BROWN, S.L.; HESTERBERG, D.; PANDYA, K. Metal bioavailability and speciation in a wetland tailings repository amended with biosolids compost, wood ash and sulfate. Journal of Environmental Quality, v.32, p.851-864, 2003.

EL-KENAWY, Z.A.; ANGLE, J.S.; GEWAILY, E.M.; EL-WAFAI, N.A.; VAN BERKUM, P.; CHANEY, R.L.; IBEKWE, M.A. Zinc and cadmium effects on the early stages of nodulation in white clover. Agronomy Journal, v.89, p.875-880, 1997.
FOREST_SERVICE. Wenatchee National Forest Website, 2004. Available in: http://www.fs.fed.us/r6/wenatchee/holden-mine/. Accessed at: 02/14/2004.

GENTILI, F.; HUSS-DANELL, K. Local and systemic effects of phosphorus and nitrogen on nodulation and nodule function in Alnus incana. Journal of Experimental Botany, v.54, p.27572767, 2003.

GILLER, K.E.; MCGRATH, S.P.; HIRSCH, P.R. Absence of nitrogen fixation in clover grown on soil subject to long-term contamination with heavy metals is due to the survival of only ineffective Rhizobium. Soil Biology and Biochemistry, v.21, p.841-848, 1989.

GILLER, K.E.; KEN, E.; WITTER, E.; MCGRATH, S.P. Toxicity of heavy metals to microorganisms and microbial processes in agricultural soils: A Review. Soil Biology and Biochemistry, v.30, p.1389-1414, 1998.

GILLER, K.E.; WITTER, E.; MCGRATH, S.P. Assessing risks of heavy metal toxicity in agricultural soils: Do microbes matter? Human and Ecological Risk Assessment, v.5, p.683-689, 1999.

HARDY, R.W.F.; BURNS, R.C.; HOLSTEN, R.D. Applications of the acetylene-ethylene assay for measurement of nitrogen fixation. Soil Biology and Biochemistry, v.5, p.47-81, 1973.

HENRY, C.L.; SULLIVAN, D.; RYNK, R.; DORSEY, K.; COGGER, C. Managing nitrogen from biosolids. Seattle: Washington State Department of Ecology, 1999. 57p.

HORSWELL, J.; SPEIR, T.W.; VAN SCHAIK, A.P. Bio-indicators to assess impacts of heavy metals in land-applied sewage sludge. Soil Biology and Biochemistry, v.35, p.1501-1505, 2003.

HUSS-DANELL, K.; GENTILI, F.; VALVERDE, C.; WALL, L.; WIKLUND, A. Phosphorus is important in nodulation of actinorhizal plants and legumes. In: FINAN, T.M.; O'BRIAN, M.R.; LAYZELL, D.B.; VESSEY, J.K.; NEWTON, W. (Ed.) Nitrogen fixation global perspectives. Hamilton: Oxford University Press, 2001. p.163-165.

HUTCHINSON, T.C.; WATMOUGH, S.A.; SAGER, E.P.S.; KARAGATZIDES, J.D. Effects of excess nitrogen deposition and soil acidification on sugar maple (Acer saccharum) in Ontario, Canada: an experimental study. Canadian Journal of Forest Research, v.28, p.299-310, 1998.

IBEKWE, A.; ANGLE, J.S.; CHANEY, R.L.; VAN BERKUM, P. Enumeration and N2 fixation potential of Rhizobium leguminosarum biovar trifolii grown in soil with varying $\mathrm{pH}$ values and heavy metal concentrations. Agriculture Ecosystem and Environment, v.61, p.103-111, 1997.

KEENEY, D.R.; NELSON, D.W. Nitrogen - Inorganic forms. In: PAGE, A.L. (Ed.) Methods of soil analysis. Part 2. Chemical and microbiological properties. Madison: ASA; SSSA, 1982. p.643-649.

KRAMER, P.A.; ZABOWSKI, D.; SCHERER, G.; EVERETT, R.L. Native plant restoration of copper mine tailings: II. Field survival, growth, and nutrient uptake. Journal of Environmental Quality, v.29, p.1770-1777, 2000a.

KRAMER, P.A.; ZABOWSKI, D.; SCHERER, G.; EVERETT, R.L. Native plant restoration of copper mine tailings: I. Substrate effect on growth and nutritional status in a greenhouse study. Journal of Environmental Quality, v.29, p.1762-1769, 2000b.

LI, Z.; RYAN, J.A.; CHEN, J.; AL-ABED, S.R. Adsorption of cadmium on biosolids-amended soils. Journal of Environmental Quality, v.30, p.903-911, 2001.

MARTIN, K.J.; POSAVATZ, M.J.; MYROLD, D.D. Nodulation potential of soils from red alder stands covering a wide age range. Plant and Soil, v.254, p.187-192, 2003.

MCGRATH, S.P.; CHAUDRI, A.M. Letter to the editor - Longterm effects of metal contamination on Rhizobium. Soil Biology and Biochemistry, v.31, p.1205-1207, 1999.

MONACO, P.; CHING, K.; CHING, T. Host-endophyte effects on biomass production and nitrogen fixation in Alnus rubra actinorhizal symbiosis. Botanical Gazette, v.143, p.298-303, 1982. 
MYROLD, D.D.; RUESS, R.W.; KLUG, M.J. Dinitrogen fixation. In: ROBERTSON, P.; COLEMAN, D.; BLEDSOE, C.; SOLLINS, P. (Ed.) Standard soil methods for long-term ecological restoration. New York: Oxford University Press, 1999. p.241257.

NATURAL RESOURCES CONSERVATION SERVICE - NRCS. Washington: State Soil Survey Report, 2004. Available in: http:/ /www.wa.nrcs.usda.gov.

NELSON, D.W.; SOMMERS, L.E. Total carbon, organic carbon, and organic matter. In: BARTELS, J.M.; BIGHAM, J.M.; SPARKS, D.L.; PAGE, A.L.; HELMKE, P.A.; LOEPPERT, R.H.; SOLTANPOUR, P.N.; TABATABAI, M.A.; JOHNSTON, C.T.; SUMNER, M.E. (Ed.) Methods of soil analysis. Part 3. Chemical methods. Madison: SSSA; ASA, 1996. p.961-1010.

OBBARD, J.P.; JONES, K.C. The effect of heavy metals on dinitrogen fixation by Rhizobioum-white clover in a range of long-term sewage sludge amended and metal-contaminated soils. Environmental Pollution, v.79, p.105-112, 1993.

RICHARDS, J.; KRUMHOLZ, G.; CHVAL, M.; TISA, L. Heavy metal resistance patterns of Frankia strains. Applied and Environmental Microbiology, v.68, p.923-927, 2002.

ROBERTSON, G.P.; SOLLINS, P.; ELLIS, B.G.; LAUTHA, K. Exchangeable ions, $\mathrm{pH}$, and cation exchange capacity. In: ROBERTSON, P.; COLEMAN, D.; BLEDSOE, C.; SOLLINS, P. (Ed.) Standard soil methods for long-term ecological research. New York: Oxford University Press, 1999. p.106114.

ROJAS, N.S.; LI, C.Y.; PERRY, D.A.; GANIO, L.M. Frankia and nodulation of red alder and snowbrush grown on soils from Douglas-fir forests in the H.J. Andrews experimental forest of Oregon. Applied Soil Ecology, v.17, p.141-149, 2001.

RYTTER, L.; ARVEBY, A.S.; GRANHALL, U. Dinitrogen (C2H2) fixation in relation to nitrogen fertilization of grey alder (Alnus incana (L.) moench.) plantations in a peat bog. Biology and Fertility of Soils, v.10, p.233-240, 1991.

SAYED, W.F. Effects of land irrigation with partially-treated wastewater on Frankia survival and infectivity. Plant and Soil, v.254, p.19-25, 2003.

SAYED, W.F.; MOHAOWAD, S.M.; ABD EL-KARIM, M.M. Effect of $\mathrm{Al}, \mathrm{Co}$, and $\mathrm{Pb}$ ions on growth of Frankia spp. in a mineral medium. Folia Microbiologica, v.45, p.153-156, 2000.

SMITH, S.R. Rhizobium in soils contaminated with copper and zinc following the long-term application of sewage sludge and other organic wastes. Soil Biology and Biochemistry, v.29, p.1475-1489, 1997.
SOPPER, W.E. Revegetation of a contaminated zinc smelter site. Landscape and Urban Planning, v.17, p.241-250, 1989.

SPSS INC. SPSS 12 for Windows. Chicago, Il., 2003.

TEKLEHAIMANOT, Z.; MARTIN, R. Diurnal and seasonal patterns of nitrogenase activity of red alder in comparison with white clover in silvopastoral agroforestry systems. Biology and Fertility of Soils, v.28, p.267-270, 1999.

TRAINA, S.J. The environmental chemistry of cadmium. In: MCLAUGHLIN, M.J.; SINGH, B.R. (Ed.). Cadmium in soils and plants. Dordrecht: Kluwer Academic Publishers, 1999. p.11-38.

ULIASSI, D.D.; RUESS, R.W. Limitations to symbiotic nitrogen fixation in primary succession on the Tanana River Floodplain. Ecology, v.83, p.88-103, 2002.

USEPA. SW-846 - Test methods for evaluating solid waste Physical/chemical methods. Method 3050B: Acid digestion of sediments, sludges, and soils. Washington, DC, 1986. Available in: http://www.epa.gov/sw-846/3_series.htm. Accessed at: 10/ 02/2001.

USEPA. A guide to the federal EPA rule for land application of domestic septage to non-public contact sites. Washington, DC, 1993. 87p. (EPA/832-B-92-005, WH-547).

USEPA. Biosolids generation, use and disposal in the United States. Washington, DC, 1999. (EPA 530-R-99-009, 5306W). VERGHESE, S.K.; MISRA, A.K. PCR-RFLP Based screening of Frankia in alder nodules having different levels of nitrogenase activity. Symbioses, v.28, p.337-350, 2000.

WALL, L.G. The Actinorhizal symbiosis. Journal of Plant Growth Regulation, v.19, p.167-182, 2000.

WEAVER, R.W.; DANSO, S.K.A. Dinitrogen fixation. In: WEAVER, R.W.; ANGLE, J.S.; BOTTOMLEY, P.S. (Ed.) Methods of soil analysis. Part 2. Chemical and microbiological properties. Madison: SSSA; ASA, 1994. p.1019-1023.

ZAR, J.H. Biostatistical analysis. Upper Saddle River: PrenticeHall, 1996. 662p.

Received March 07, 2006

Accepted June 17, 2006 